\title{
Problem of "Dinosauring" of European Union and Mapping of Its Future
}

\author{
Egidijus Vareikis \\ Correspondence: Egidijus Vareikis, Parliament of the Republic of Lithuania, Vilnius, Lithuania
}

Received: May 5, 2016 Accepted: May 11, $2016 \quad$ Online Published: May 19, 2016

doi:10.11114/smc.v4i1.1617

URL: http://dx.doi.org/10.11114/smc.v4i1.1617

\begin{abstract}
Numerous national and international institutions perform exercises for future prediction. Generally, their "products" are predicting optimistic, politically correct and logic outcome, that is far from reality. European Union (EU) planners generally like to limit themselves on short-term (not longer than ten years) future predictions that seems to be more technical improvements rather than on strategic reorganization of the EU in that changing world. However European Union, being in crisis need to develop the long-term strategy for changes. One of the weak points of EU existence is the constant will to avoid the decision to make a choice.

The popular European vision of its future can be called The Davos World - simple scenario based of the economic benefits, predicting that the driving force for ruling the world will be the endless economic interest. However, EU will hardly implement this idea because of current and ongoing problems. EU is design to adopt itself to changing realities rather to create realities itself. The popular future scenarios mentioned: Pax Americana, "The union of Dragoon and Bear", The New Caliphate, The World of Fear, BRIC, The New Messiah, do not foresee long time successful future for EU. The possibilities of post-EU Europe: New Kalmar Union, New Switzerland, New Lithuanian-Polish Commonwealth, Fourth Rome are discussed.
\end{abstract}

Keywords: European Union, future, scenario, development, methodology, strategy

\section{Introduction}

\subsection{Future Prediction - the Important Issue between Phantasy and Science}

There are no doubt lot of discussions on the events and situations one can expect in ongoing decades of 21 st century. The scale of predictions vary from totally optimistic to completely negative. Mankind is been threatened in the past with different apocalyptic scenarios like nuclear annihilation or space intruders. The climate change, energy disasters, population flows are the main treats now (Lombardo, 2006). Despite the very complex situation, the strategists of politics and civilization history are trying to say, what we all have to expect (Global Trends 2030, 2014). Thus, the general scenarios for the future and special ones (emphasizing one particular area as climate change, development of education, energy supply, etc.) are been created in large numbers. Sometimes they look like fairytales, sometimes as set of rules (currently generally called "the road map") (Note 1.). The ideological, political and moral problems are more unpredictable and have no instruments for solutions. Looks like these problems cannot be solved using the political decisions, modern technologies or by market self-regulation.

One of buzzy invention of recent years is so-called strategic planning, that includes writing of short, middle term and long-term strategies (Mintzberg, Lampel, Ahlstrand, 2005). Numerous national and international institutions perform some exercises for future prediction (e.g. http://pardee.du.edu/). Some countries of European Union write their own strategic visions. Few years ago the Lithuanian parliament adopted the strategy "Lithuania 2030". According it the country has to be happy with smart administration, smart technologies and smart society well adopting itself to the global challenges (http://www.lietuva2030.lt/, 2014). The similar Polish strategy pays more attention to technological innovations. Latvians "look for happiness" in securing of national heritage, Estonian "dream" is the natural environment that makes life healthy and pleasant. The Finnish strategy is marked by the wishes to have more services for hedonistic way of life. One can present the long lists of institutions, NGOs and different working groups preparing British, German or American plans for the future and writing various studies (Alesina, Giavazzi, 2006).

This is of course the interesting exercise and sometime governments even pay for these writings, however almost all the "official" or state-bought strategies have at least four negatives that make them almost worthless.

Firstly, all they have to predict the optimistic result. The real life however shows, that there are not only good times in 
the future, it is rather opposite. Thus, the strategy is a failure from the beginning.

Secondly, the strategy has to be politically correct. Nobody will predict the war, economic hardship and natural disaster, that government is unable to tackle. History however teach us, that problems are been solved in the battlefield more frequent than with the methods of healthy competition.

Thirdly, written strategy has no or very little reference to the spiritual (cultural, patriotic, nationalistic, religious) dimension of strategy. This sometimes is even more important than economy that look like be simple to calculate.

Fourthly, there are unexpected events of life- "black swans"- that change the sometimes in more radical way that it is predicted in the social projects. Moreover, even those strategists, who see the world predictable, are limited in their thinking facing so called idols of Francis Bacon. All the impartiality can be easily replaced with emotional and irrational decisions, i.e. it is impossible to liberate from stereotypes, definitions or lack of knowledge (Hesse, 1964).

Because of that some pessimistic predictions as Sweden 2030, that predict Sweden becoming poor country are not popular among officials

(https://disqus.com/home/discussion/speisa/sweden_to_become_a_third_world_country_by_2030_according_to_un/).

It is important to add, that numerous authors of strategies like to limit themselves on short-term (not longer than ten years) future predictions that seems to be more realistic and producing predictable results. The extrapolation of these results into long-term perspective however generally lead to significant mismatches with realities. This is a case for European Union it by definition cannot predict what will happen after the union well cease to exist. It is very difficult even to ask EU officials to think about the reform, because the EU is created to exit without reforms, and for progress only. So the European Union and its planners are obliged to stick to the optimistic and politically correct scenarios. It is against the spirit of the Union to work with any spiritual predictions and "black swan" appearances. Because of that EU produces only short term predictions or technical improvements rather than strategic reshape of the organization in that changing world.

In my early writings, I called it the process of "dinosauring" (Vareikis, 2002). In other words, it means, that the system is becoming the project running and problems solving organization. It adopts to the new realities using the internal resources until they are exhausted or possibilities to produce them are vanishing. Dinosaur is strong and impressive; however, it is dying because of no means of adaptation.

\section{Methods of Future Prediction}

The extensive overview of most popular methodologies in future prediction was presented elsewhere (Vareikis, 2015). In this paper I mention briefly the main points of methodology used.

All the thinkers, making long-term scenarios, have in fact to answer to six fundamental questions (Inayatullah, 2004). What is a future of us as physical and biological objects? What is the future we afraid of, what we would like to avoid? What are the values and stereotypes we are ready to defend, and what we are ready to get rid of? Do we have alternatives to our stereotypes? What is the desirable picture of our futures? Are we powerful enough to bring our plans to reality, i.e. do we have enough resources for our plans?

Civilization, that wants to predict its future, or even to create its future, has to answer these questions or at least set the list of dreams about desirable outcomes. Of course, several factors, mostly of ideological nature diminish the scientific significance of the answers. Theoreticians and practicians often base their ideas of some typical frameworks. Some of them are worth to be mentioned (Inayatullah, 2008). http://www.metafuture.org/

\subsection{Used Future}

Prediction of the future based on existing "success story" or the successful country. The safe ideas to create New America, Scandinavian model, New Caliphates, etc (Sheppard, Hartwick, Warshaw, 1988).

\subsection{Disowned Future}

The future is constructed to get rid of mistakes of the past and avoid them in the future, i.e to remove the negatives of policy from the social life, for example, to remove the phenomena such as Nazism, racism, social inequality etc. (Inayatullah, 2010).

\subsection{Alternative Futures}

Popular method in predicting the influence of one particular parameter - demography, climate change, etc. What will happen if the nation will secure its identities, or in the case they will ignore, will be influenced by cultures of another civilizations (Pedersen, 2001). 


\subsection{Alignment}

These are scenarios for case of life in the society made by internal regulations. The government can support (legally or financially) some positive trends and suppress the negative ones (the building of communism was one of them). It attracts many writers, because one can present even logic quantitative measurements of the futures, and it is well supported by different business and interest groups (Sender, 1997).

The methodology of prediction has to take into account the understanding the history itself. One can see history as continuous cyclic, "sinusoid" or even discontinuous chaotic process: Plato's cyclical changes is social development, the line approach of saint Augustin in his "City of God, "zig-zag" history of Machiavelli, some "progressive" and "regressive" trends, theories talking about traditional, industrial, postindustrial societies, modern and postmodern state of social groups.

The factors that can be partially under regulation are for example related with the shrinking of state influence and number of state functions (Ham, 2001). There is constant discussion in Europe - what is better: EU institutions or national parliament. EU is still economically and legally powerful, but very remote from average citizen. The negative side of globalization - international terrorism, organized crime, proliferation of weapons of mass destruction, "asymmetric treats", epidemics, migration has to be taken into account (Bird, Blomberg, Hess, 2008).

There are factors impossible to avoid. These are demography (the human population growths and it will reach maybe 9 billion in 2050, if no any global disasters occur; Pew Research Center, 2014); climate change (Houghton et al., 2001); generation of energy, disproportions in access, price, etc (REN21). There is also the irrationality of society, religious extremism, glorification of celebrities, diminished authority of science and logic. This is a postmodernism in a broader sense that does not corresponds to general understanding of modernity and modernization.

The concept of "waves of democracy" is the classical example of cyclical development, described in political science texts (Markoff, 1996, Sartori, 1987, Huntington, 1991, Kurzman, 1998). The clearest observation of these "waves" can be observed in Latin America. The political system (or its mask) is changing in twenty years intervals - dictatorships are been replaced by democracies and vice versa. It was observed in this region already for century. Similar picture is in Africa. Waves in reality can be related to generation change, and the new ideas, that have ,critical mass support periodically. The waves are more "clear" in the regions; there the societies are not extremely affiliated to constitutions, national histories and stability of the state. Waves are interrupted by wars and other global and regional disasters. In Europe we can observe rise of democracy in - 1945-1950, 1985-1990 and maybe 2025-2030. There are the periods of some disappointment in 1965-1970, and probably now.

In $19^{\text {th }}$ and $20^{\text {th }}$ centuries dozens of social and economic development laws and economic "waves" were discovered. The shortest waves (or cycles) in economic development, called short business cycles, last 3-5 years (40 months) (Kitchin, 1923). The origin of them is in some "human factor" - companies react to the changes in the market with some delay and try to "catch up" later, they try to increase production or services amount, try to employ more people however avoiding investments and capitals. Longer lasting waves last 5 to 10 years and are related with so-called Clement Juglar phenomena, first described on 1862. It states, that larger investments wave much slower, than short time waves(Guillaumin, 1862). There is the evidence of 10-25 years cycles, the massive investments, renovations or new constructions, introducing new technologies and sophisticated infrastructure (Kuznets, 1955).

Probably the most interesting in this context are the long term (40-60 years) waves - so called Kondratyev waves in economic development. These are of extreme importance, because ups and downs of them are related with wars, changes of political ideologies, etc.(Korotayev, Tsirel, 2010).

Kondratyev cycles are related with social shifts as well. The probability of the war is higher in the initial phase of the way or growing period that can be called "spring time". In "summer time" we have period of stagnation caused by higher life standard and better social security. In declining period - "autumn time" the authorities look for stability than for new ideas, and it causes the "winter", that is the major crisis. We had the intensive growth periods in 1853-1873 and 1951-1973, partially good growth in 1873-1913 and after 1973 till current major crisis. Whereas 1913-1951 is a time of greater decline (Lewis, 1954).

There is also so called Saeculum theory about the 90 year cycles, i.e the time from some important event (for example declaration of state independence) until all the „participants“ of this event die. Maybe this is the prolonged Kondratyev way only, but the evidence say it can be important for future prediction (Galland, 2009).

USSR as an entity existed for app. 70 years, the same life-time was of Bismarck's Germany. Now we have 70 years after World War II with all the postwar developments, i.e European integration. Does it is going to the end? EU is not aging demographically. Is it the "retired" political ideology? Maybe the real end of European integration is approaching? 
Can EU survive or transform? It depends what it will decide, which archetype of evolution it is accepting. Jim Dator (http://www.jfs.tku.edu.tw/14-2/E01.pdf) presents few proposals that EU in fact can take into account: growth with new technologies, decline as society facing the external pressure, or find the ability to stabilize the current situation?

Thus, the set of instruments to create scenario for the future is huge, but anyway, there is a powerful "human" factor: existing stereotypes, dreaming, o requirements to fulfill the needs, the strategic goal of the authorities, who finance all this business. One of the weak points of European Union existence is the constant will to avoid the decision to make a choice. The essence "dinosauring" is to prolong the today's welfare instead of prepare to changes. Today EU really did not make a choice.

\section{Results}

\subsection{The Evaluation of Different Factors of Development and "Dinosauring"}

The numerous writings and publications of future strategies can be divided into few stereotypical models and future visions. The aim of this chapter is to list them and to reflect, where EU place in them is. Does EU has its scenario, if yes, how logic it is? If not, what is the EU future in other scenarios?

The most logic European vision of its future can be called The Davos World, named after the name and ideology, of annual World Economic forum (http://www.weforum.org/community/strategic-foresight, 2014). This is simple scenario based of the economic benefits, predicting that the driving force for ruling the world will be the endless economic interest - to consume more and to possess more. Information society and postmodern habits have to serve to increase area of consumption. In general this is scenario for no any changes and attempt to fix the mankind in the present stage of the development. The only change can be a change of main producer - it will be Asia, however, the „redistribution "will remain in the hands of Europeans and Americans, even if the Asians themselves will become the main consumers.

However, European Union will hardly implement Davos' idea. It is facing the serious problems: these are external challenges as well as the internal problems of consolidation, legitimacy, democratic deficit, etc. It need the reform, reset or... dissolution. European integration started as probably the great and successful peace-building project, however current status of EU does not corresponds with idea of integration for peace. It is rather related with the huge economic power, personal freedoms and social guarantees. Some decades ago indeed, it "took" Greece to prevent its shift toward Moscow, but now many say, it is no need to take Ukraine closer to the Union for the same reason, or not to allow the Islam world to take Turkey. All the world order is based on European or euro-atlantic identity, but this identity is never described as universal (Maly, 2010).

When the end of EU will come? It will come with the crisis that EU development does not predicts and will be not able to solve with existing means. It is been emphasized by many authors (Piris, 2012). It needs the strong political leadership not only for the future but even for today. It needs stronger leadership, but not only (Conley, Heather, 2011). EU is a system, that is adopting itself to the situation, but is very little able to change it or to impose its ideas. Today EU needs regional stability much more than it needs justice, democracy or human rights in the world. Every country joining the Union has to adopt it rather than to enrich it with new quality.

No one among famous political thinkers imagines successful long being of EU, because it is not clear what are the EU long-term perspectives except maintenance of "beautiful today". Once it was idea, that we have to trust God, and go to liberate the Tomb of Crist, to export ones beliefs overseas. Later there was a trust into military force, scientific achievements and free market. Today's integration started with the idea to prevent further wars, but it is not actual any more.

Generally, the destiny of EU will depend on the core values that society will be ready to defend. This are the main message of political writers and thinkers.

\section{Discussion}

Does EU has a future in other popular long time predictions?

American vision - Pax Americana, the World dominated by USA, look to a finalite politique described Francis Fukuyama (Fukuyama, 1992). European Union or some other Europe can be in it, no matter. The only requirement is to follow principles of classical liberal democracy. From other side Pax Americana often looks like "yesterday's story" with no bright future itself.

Chinese-Russian vision "The union of Dragoon and Bear" is based mostly on kind of cinophylia and cinophobia. The base for Chinese and Russian dream is simple pragmatism. Chinese think and have reason to do so, that the World fear not to receive Chinese products is bigger, that Chinese fear to loose markets. Economy is above the human rights and freedoms - this is a victory of primitive Marxism that in reality means the progress achieved by low paid job and almost slavery. Many say, that 21 st century has to be Asian or Eurasian century. There is no secret that in recent decades there 
were lot of optimistic predictions for China. This country will rule the world, and we have to be prepared for this historic fact (Ikenberry, 2008). Does EU matters in this scenario? Not at all.

Islamic vision - The New Caliphate (Danforth, 2014). This is World order based on the primacy of religion, one of the examples of renascence and modification of one of the main religious faiths. EU today has no any religious policy (it was rejected as not important) and in the best case scenario can only agree with the rules set by New Caliphate.

The World of Fear - "orwellian" vision - predicts the world in which the main part of population are poor or "losers" who are willing to accept the dictate of the government (Orwell, 1949). This is also hardly applicable to the EU.

In recent years many authors propose so-called BRIC (or similar) scenario for medium term global multipolar future. The main countries in this project have to be Brazil, Russia, India, China (maybe also South Africa) (http://www.bricsforum.org/). This would be a good multi visual project, however it has few serious obstacles - all the countries mentioned has their internal problems that hardly allow them to become the leaders of the group. EU can exist in that, however without any political significance.

Finally The New Messiah - is one more rather unofficial vision. This is in people's hearts rather than on officially recognized programs. It looks like politically incorrect to speak about this, though nobody reject the appearance of "black swan" in the future. Political and social scientists try to look to the life of the society as the phenomena not very much dependent on man's emotions and even though, they recognize, that that society needs new personalities, new leaders, worth to be trusted, thus it needs new Messiah. Two thousand year ago Jesus destroyed the spirit of Ancient Roma, thus destroyed the World order of that time. The waiting for Messiah would be the logic solution of all shortages or previous visions. Surprisingly EU can stay in it transforming its "spiritual life".

\section{Conclusion or Way forward}

Some proposals of future of Europe are indeed in the limits of logic. What can happen if EU will finish its existence? There are few geographical visions of the process.

Swedish historian Gunnar Wetterberg propose to revise the idea of former Kalmar Union, that in $14^{\text {th }}-16^{\text {th }}$ centuries allowed to harmonize union under one monarch with the national aspirations of its members (Wetterberg, 2010). The today's Kalmar Union with Greenland and Island, with some additional lands as Estonia would have 3.5 million square kilometers and app. 26 million inhabitants. Union could be attractive to Dutch and Flams (if they are tired of Belgium). Most important - thus would be the top 10 economy in the world and will require equal treatment in negotiations with Americans or Germans. Scandinavians now don't want to be new Vikings, but who know what will be in the future.

The other post EU possibility - New Switzerland. Some centuries ago it was the artificially created state, that finally became the example of peaceful coexistence of different communities. Why not to expand it into northern Italy, southern Germany and even more...? From Belgium to Slovenia? The successful "Suisse project" can be 450 thousand square kilometers and 70 million inhabitants as well as the fourth economy in the World. Something more much better than European Union?

German political scientist and historian Gunnar Heinsohn says in his few public statements, that money is not the primary importance in the future. The biggest problem for central Europe is a fear of Russia. Why not to create something as new Lithuanian-Polish Commonwealth, that can be the strong state "from sea to sea" with more than 100 million people. This corresponds with idea of Zbigniew Brzezinski, who said it would limit significantly Russia's will to "go to Europe" by territorial expansion. Finally George Friedman support this idea of growing Poland and declining Germany, writing, that "new Poland" is the geographical future of central Europe. Russia is indeed the European problem from $18^{\text {th }}$ century, when this country started its way to Europe. Norman Davies says clearly, that from that time it is real problem for Europe and for Russia itself (Davies, 2014).

And why not to try the Fourth Rome taking territories of both North and South Mediterranean together? This would be chance to "balance" Turkey and all Islam World.

Finally it has to be said, that Brexit or Grexit are in facts the warming signals, that real changes are approaching. According Darwinian evolution concept birds were the dinosaurs, who avoided extinction. Is EU ready to fly? Looks, like no. And it is the most dangerous observation.

\section{References}

Alesina, A., \& Giavazzi, F. (2006). The Future of Europe: Reform or Decline. Massachusetts Institute of Technology.

Bird, G. S., Blomberg, B., \& Hess, G. D. (2008). International Terrorism: Causes, Consequences and Cures. The World Economy, 31(2), 255-274. http://dx.doi.org/10.1111/j.1467-9701.2007.01089.x 
Conley, H. A. (2011). The end of The West: The Once and Future Europe. International Affairs, 87(4), 975-984. http://dx.doi.org/10.1111/j.1468-2346.2011.01014.x

Danforth, N. (2014). The Myth of the Caliphate, The Political History of an Idea. Foreign Affairs

Davies, N. (2014). Europe: A History. Kindle Edition

Fukuyama, F. (1992). The End of History and The Last Man. Free Press.

Galland, D. (2009). Into The Fourth Turning: A Casey Research Interview With Neil Howe, Co-author of The Fourth Turning. Casey Research Special Report.

Global Trends 2030: Alternative Worlds. National Intelligence Council. CreateSpace Independent Publishing Platform (2012). www.dni.gov/nic/globaltrends; (2014) Wider perspective http://www.futuretimeline.net/

Guillaumin (1862). Des Crises commerciales et leur retour periodique en France, en Angleterre, et aux Etats-Unis. Paris

Ham, P. (2011). The Rise of the Brand State: The Postmodern Politics of Image and Reputation Foreign Affairs, 80(5), $2-6$.

Hesse, M. B. (1964). Francis Bacon's Philosophy of Science in A Critical History of Western Philosophy. D. J. O'Connor, New York, http://www.sirbacon.org/links/4idols.htm.

Houghton, J. et al. (2001). Climate Change 2001: The Scientific Basis. Cambridge University Press.

Huntington, S. (1991) The Third Wave: Democratization in the Late Twentieth Century. University of Oklahoma Press.

Ikenberry, G. J. (2008). The Rise of China and The Future of The West. Can The Liberal System Survive? Foreign Affairs, 1.

Inayatullah, S. (2008). Six pillars: futures thinking for transforming. Foresight, 10(1), 4-21. http://dx.doi.org/10.1108/14636680810855991

Inayatullah, S. (2010). Theory and Practice in Transformation: The Disowned Futures of Integral Extension. Futures, 42(2), 103-109. http://dx.doi.org/10.1016/j.futures.2009.09.002

Inayatullah, S., Bussey, M., \& Milojević, T. I. (2004). Neohumanist Educational Futures: Liberating the Pedagogical Intellect. Tamkang University Press.

http://www.veoh.com/watch/v18647040KdFfZ7Nx?h1=Futures+Thinking+for+Transformation+-+Six+Pillars+of +Futures+Studies+by+Sohail+Inayatullah, retrieved 18.12.2014.

Kitchin, J. (1923). Cycles and Trends in Economic Factors. Review of Economics and Statistics, 5 (1), 10-16. http://dx.doi.org/10.2307/1927031

Korotayev, A. V., \& Tsirel, S. V. (2010). A Spectral Analysis of World GDP Dynamics: Kondratiev Waves, Kuznets Swings, Juglar and Kitchin Cycles in Global Economic Development, and the 2008-2009 Economic Crisis. Structure and Dynamics, 4(1), 3-57.

Kurzman, C. (1998). Waves of Democratization. Comparative International Development, 33(1), $42-64$. http://dx.doi.org/10.1007/BF02788194

Kuznets, S. (1955). Economic Growth and Income Inequality. American Economic Review, 45, 1-8.

Lewis, W. A. (1954). Economic Development with Unlimited Supplies of Labor. Manchester School of Economic and Social Studies, 22, 139-91. http://dx.doi.org/10.1111/j.1467-9957.1954.tb00021.x

Lombardo, T. (2006). Contemporary Futurist Thought: Science Fiction, Future Studies, and Theories and Visions of the Future in the Last Century. Author House.

Malý, I. (2010). Europe and Contemporary Global Civilization: Its Inhertinance and Future. The Prague Journal of Central European Affairs, 11(4), 4-5.

Markoff, J. (1996). Waves of Democracy: Social Movements and Political Change. SAGE publications.

Mintzberg, H., Lampel, J., \& Ahlstrand, B. (2005). Strategy Safari: A Guided Tour Through The Wilds of Strategic Management .Free Press.

Orwell, G. (1949). Nineteen Eighty-Four. New York: Harcourt, Brace.

Pedersen, P. B. (2001). Multiculturalism and the Paradigm Shift in Counselling: Controversies and Alternative Futures. Canadian Journal of Counselling, 35(1), 15-25.

Pew Research Center (2014). Attitudes About Aging. A Global Perspective. http://www.pewglobal.org/files/2014/01/Pew-Research-Center-Global-Aging-Report-FINAL-January-30-20141.pd $\mathrm{f}$ 
Piris, J. C. (2012). The Future of Europe: Towards A Two-Speed EU? Cambridge University Press. REN21 Renewables Global Futures Report (GFR). ISEP (Institute for Sustainable Energy Policy of Japan) Press.

Sartori, G. (1987). The theory of democracy revisited. Part II. New York: Chatham House.

Sender, S. W. (1997). Systematic Agreement: A Theory of Organizational Alignment. Human Resource Development Quarterly, 8(1), 23-40. http://dx.doi.org/10.1002/hrdq.3920080105

Sheppard, B. H., Hartwick, J., \& Warshaw, P. R. (1988). The Theory of Reasoned Action: A Meta-Analysis of Past Research with Recommendations for Modifications and Future Research. Journal of Consumer Research, 15(3), 325-343. http://dx.doi.org/10.1086/209170

Vareikis, E. (2002). Dinozaurëjanti Europa. Strofa.

Vareikis, E. (2015). World Future Mapping and Scenarios for The $21^{\text {st }}$ Century. Lithuanian Annual Strategic Review 2014-2015, 13, 11-26.

Wetterberg, G. (2010). The United Nordic Federation. Copenhagen: Nordic Council of Ministers.

\section{Notes}

Note 1 . The kind of fairytale is the peotical story „Ruhnama“ („Book of Soul“) of former Turkmen prezident Nijazov about the briliant future of his country (http://www.ruhnama.info. 2014). The more serious is the 2050 vision of Kazakh prezident Nazarbayev, thought it is also more the geopolitical dream than the reflection of real possibilities (http://www.kazakhembus.com/in_the_news/president-nursultan-nazarbayevs-2014-the-state-of-the-nation-address). 